\title{
HÆMATOPORPHYRINURIA, WITH REPORT OF A CASE FOLLOWING THE USE OF TRIONAL.'
}

\author{
BY ROBERT E. RUEDY, A. M., M. D., \\ Pathologist of the Columbus State Hospital, Columbus, Ohio.
}

As long ago as 1844 Mulder and Van Gondovoer (I) prepared from hæmatin an ironfree substance, which in $187 \mathrm{I}$ was exhaustively investigated and described both as to its chemical and spectroscopic properties by Hoppe-Seyler (2), who gave to it the name of Hæmatoporphyrin. This substance first assumed a clinical importance when, in 1880 , Mac Munn (3) reported finding it in the urine of patients with various diseases, among them rheumatism, Addison's disease, pericarditis, and paroxysmal hæmoglobinuria. Others reported similar findings, as Le Nobel (4) in rheumatism, in two cases of cirrhosis of the liver, in pneumonia, in hæmorrhage of the stomach, and in pericarditis. Goya (5) and Garrod (6) report finding this substance in various liver diseases, the latter believing that latent disease of the liver might thus be diagnosticated, although he was unable to offer any explanation.

A number of cases of lead-poisoning are reported, where hæmatoporphyrin appeared in the urine, Stokvis (7) declaring it to be a constant symptom. Other cases are reported by Binnendijk (8), Nakarai (9), and Schulte (Io).

Moreover, it appears that this substance may be found in some cases in the urine of otherwise healthy individuals. Garrod (9) claims that it is frequently found in small quantities, Stokvis and Klees (7) claim to find traces of it in the dark urine of healthy individuals, and Sobernheim (II) details at length the case of a I3-year-old boy, who for years had the characteristic dark urine in which hæmatoporphyrin could be demonstrated without presenting any other symptoms of ill health.

\footnotetext{
${ }^{1}$ Read at the meeting of the Association of Assistant Physicians of Hospitals for the Insane, at Cleveland, Ohio, September 28, 1899.
} 
Garrod (12), who has done a large amount of work on this subject, found hæmatoporphyrin in a large number of pathological conditions, as the acute infectious diseases, a dropsical case without special cause, paroxysmal hæmoglobinuria between attacks, and in various forms of tuberculosis. The painstaking investigations of Nakarai (9) in the clinic of Prof. Curshmann at Leipzig deserve special mention. He made frequent examinations of the urine of 144 patients representing 39 different diseases. Of these ro showed hæmatoporphyrin spectroscopically, although the color of the urine was by no means always characteristic, being at times reddish-yellow, rose-yellow, or even waterclear, viz., of these 6 were of lead-poisoning (all), 2 cases out of 4 of tuberculosis, I of rheumatism, and I of empyrma. His observations bear out the statement of Stokvis that hæmatoporphyrinuria is a constant symptom of lead-poisoning. The amount stood in no relation to the severity of the symptoms, and continued even in considerable quantity when the patient had so far recovered as to leave the hospital. Positive results followed in the 2 tubercular cases after severe intestinal hæmorrhages. The empyæma case was undoubtedly one of sulphonal intoxication, the patient having taken $46 \mathrm{gm}$. of sulphonal in 76 days in I gm. daily doses, with a rest of 30 days in the middle of the time.

Since 1888 , when Baumann and Kast first introduced sulphonal as a hypnotic, the subject of hæmatoporphyrinuria has assumed a much greater clinical importance. In half a dozen years Friedlander (13) could find over Ioo cases where symptoms of intoxication developed following its use, most important both in acute and chronic intoxications being the effect on the blood as evidenced by the urine, which is described as dark-brown-red, brown-red, cherry-red, Bordeaux-red, colors depending on the hæmatoporphyrin they contain. While all these cases agree as to the peculiar color of the urine, exact demonstrations of hæmatoporphyrin are reported in 23 of them, viz.: Salkowski (14), 3; Jolles (15), 4; Stern (16), I; Hammersten (17), 2; Mueller (18), 2; Panking and Pardington (19), 2; Stokvis (7), I; Schaffer (20), I ; Bresslauer (2I), 7.

Oswald (22), reporting in 1895 a fatal case following the use of sulphonal, states that 40 cases of a similar nature had been noted, all in women and over half fatal. More recently other 
cases with autopsy are reported by Marthen (23), Schulte (10), Pollitz (24), and Wien (25). And in addition about a dozen cases $(26,27,28,29)$ are reported where a similar condition followed the use of trional. Goldmann (30) says that if trional is not carefully given hæmatoporphyrin appears in the urine, which should be carefully watched during the administration of the drug.

The case under our own observation belongs to this class, and may be briefly detailed here. R. J., female, age 39, was admitted in I884, suffering from chronic insanity with periodic acutely excited attacks lasting 4 to 6 weeks about twice a year.

Various sedatives were tried, but trional best controlled these attacks, requiring, however, sometimes $60 \mathrm{gr}$. a day for short periods. No evil effects were noted from its use. On July 5, I898, after a 4 weeks' disturbed period, during which she had taken trional as necessary almost every day, in all perhaps over an ounce, she was put to bed, being too weak to be about. She had had little appetite for some time previous, was troubled with constipation, and, never robust, had run down quite rapidly in a short time, without presenting other symptoms than those mentioned. On the 6th she was up; on the 7 th again in bed with almost complete suppression of urine, the first symptom on the part of the urine. On the 8th a small amount of urine was passed, which was of a Bordeaux-red color, acid, sp. gr. I02I, albumin positive, Esbach .5, no sugar, no bile pigment, Heller's test for hæmoglobin negative as also Teichmann's hæmin crystal test. Vigorous application of the centrifuge precipitated a slight sediment with the entire liquid above it of a uniform dark-red color. Microscopically this sediment consisted of granular and epithelial casts, renal epithelium, some large flat epithelial cells, some white blood-cells and a very few red blood-cells, by no means a sufficient number to account for the color of the urine. The examinations thus far allowed us to exclude hæmaturia, and hæmoglobinuria. In order to exclude the latter more positively, another test was made. As hæmoglobinuria is but the renal expression of a hæmoglobinæmia, if that condition existed, the blood-serum ought to show the characteristic red color of the hæmoglobin in solution. Accordingly, a few cc. of blood were drawn from the median vein, but the serum was of a clear straw 
color on coagulation. The diagnosis of hæmatoporphyrinuria was accordingly made. Unfortunately, we were not equipped to make the spectroscopic examination required in the various tests for this substance, and our diagnosis was made from and by exclusion. ${ }^{2}$

The following day the patient became comatose, and but a few ounces of urine showing the same characteristics as that previously examined, were drawn with a catheter. Blood examination made at this time showed red cells 4, I80,000, white cells 8,000, hæmoglobin (Gowers) 75 per cent.

Stained preparations showed well-formed red corpuscles with minimal form and size changes, a good hæmoglobin content and no anomalies of the leucocytes-apparently a slight degree of anæmia.

Coma deepened, suppression of urine became absolute, and patient died July Ioth, 5 days after first going to bed.

Autopsy 15 hours after death. Marked emaciation, rigor mortis present, sclera icteric. Brain, wt. I305 gm., pia and brain substance œdematous and congested. Lungs œdematous, heart in good condition. Spleen small and firm. Liver large, rich in blood, gall-bladder distended with colorless fluid and contains 36 faceted calculi, and one is impacted in the middle of the cystic duct. Hepatic and common ducts free.

Stomach slightly injected, as is also upper third of small intestine; walls thin, otherwise normal and no evidences of hæmor-

\footnotetext{
${ }^{2}$ The methods of demonstrating hæmatoporphyrin all depend on a final spectroscopic examination. Of the several methods suggested, that of Salkowski (14) is the most reliable, being able to detect quantities not demonstrable by the other methods. Von Jaksch (3I), who speaks of it especially in connection with the use of sulphonal as a dangerous symptom, and certainly not without meaning, describes Salkowski's method as follows: Thirty cc. of urine are precipitated with an alkaline barium chloride solution, the precipitate filtered and washed with distilled water and then with absolute alcohol. The moist precipitate is triturated with alcohol and hydrochloric acid, and after standing for a short time is heated on a water bath. The filtrate, which in the presence of hæmatoporphyrin is red, is then examined spectroscopically, and shows the characteristic absorption stripes, the first in the orange terminating at the line $D$, and the second broader and darker in the green between the lines $b$ and $F$. There are two other very faint and almost indistinguishable lines in the spectrum. .
} 
rhages. Kidneys large, red, cortical layer broad, not clearly defined, capsule rather adherent in places, pyramids distinctly striped red and white, blood-vessels distended and pelvis injected. Bladder contracted and contains a few drops of pinkish, slimy fluid. Aorta and arteries not changed.

Microscopically the only notable change was found in the kidneys. The glomeruli and blood-vessels were engorged with blood, and the convoluted tubules, especially those cut in crosssection, plainly showed the lumina filled with granular débris, and the epithelium swollen, irregular, detached and absent in places. There were no interstitial changes.

To show the similarity of the clinical pictures and of the postmortem findings, as observed by different men, I will briefly give a few typical cases.

Pollitz' Case (24).-Woman, puerperal mania, treated successfully with I.5, later I gm., of sulphonal daily for a year, with frequent intermissions of several weeks. Thin dark-red urine, diminished amount, constipation and loss of appetite. Condition improved several times before death.

Autopsy showed widespread disease of the secreting epithelium of the tubuli uriniferi.

Schulte's Case (10).-Woman, age 73, took during 5 weeks I gm. of sulphonal daily, became somnolent, was constipated and had retention of urine. Urine Bordeaux-red, strongly acid, no albumin, sugar or blood.

Patient claims to have noticed red color of urine for 4 weeks. With two remissions and exacerbations both of red color and of acidity, patient suddenly died with general appearance of heartfailure Io days after admission to hospital. The autopsy showed endarteritis, œdema of meninges and of lungs, slight myocardial lesions, marked granular atrophy of the kidneys, ecchymoses in the upper part of the small intestine.

The author emphasizes the moderate amount of sulphonal taken, the remission of the symptoms, the strong acidity, and the fact that the autopsy did not reveal the cause. He thinks that the hæmatoporphyrin was the expression of a severe disturbance of metabolism, accompanied by an overproduction of acids, accounting for the very acid urine.

Marthen's Case (23).-Insane woman, age 39, restless, given 
$66 \mathrm{gm}$. sulphonal in 2.5 months with frequent intermissions, 18 gm. given in the last 25 days. Patient collapsed with retention of urine. Later dark-colored urine was passed, with no albumin, sugar, hæmoglobin, or bile pigment; death in 4 days.

Autopsy, excepting a soft grayish heart-muscle, showed no noteworthy changes beyond congested kidneys, which under the microscope showed widespread affection of the secreting epithelium of the convoluted tubules and of the ascending limb of Henle's loops, with a tendency to disintegration of the centrally placed ends of the epithelium.

In Stern's case (I6) extensive necrosis of the epithelium of the convoluted tubules is also noted.

Wien's Case (25).-A woman, received $1.5 \mathrm{gm}$. sulphonal daily for a month. Persistent vomiting then developed, paresis of the lower extremities and of the muscles of deglutition, and, after 8 days, hæmatoporphyrinuria, ordinarily an early premonitory symptom, appeared. The autopsy showed double toxic nephritis, cystitis and degeneration of the blood-vessels.

Reinicke (29) reports a case where a very similar state of affairs followed the use of trional, but without a fatal ending.

It would seem that sulphonal may be taken as the representative of the class of acetonic disulphones to which it belongsthe others being trional and tetronal. It also seems probable from the number of cases ascribed to each that trional is less liable to produce toxic symptoms than is sulphonal.

Bresslauer and Joachim (32), in discussing the administration of these drugs, call attention to the evil effects following their prolonged use: I. Vomiting and constipation. 2. Ataxia of lower limbs with paralyses and muscular spasms. 3. Anuria, ischuria and hæmatoporphyrinuria, frequently fatal. Evil results are best avoided by giving the remedy not more than 3 days in succession in a dose not to exceed $2 \mathrm{gm}$. a day, and by regulating the bowels and the kidneys.

The urine should be watched, and upon becoming cloudy or dark the medicine should be discontinued at once. Should pronounced symptoms of intoxication occur, the treatment should consist of the administration of large doses of sodium bicarbonate, liberal amounts of carbonated water, diuretics and cathartics.

In regard to the prognostic value of hæmatoporphyrinuria as 
a symptom it varies greatly in the different conditions in which it is found.

It is undoubtedly a grave sign in sulphonal and trional intoxications, as of the 23 cases before referred to 9 were fatal, of Oswald's 40 cases over half were fatal, and of the 12 or 15 cases more recently reported almost all were fatal. All writers on the subject agree, and the statistics bear them out strikingly, that women have a peculiar susceptibility to the toxic action of sulphonal, Schultz finding as high as 20 women in 21 fatal cases. Various degrees of anæmia are often noted in these cases, and some are inclined to believe that persons with damaged blood are more susceptible to sulphonal-poisoning. The cases reported give no detailed accounts of blood-examinations, and our own case showed only a moderate degree of anæmia.

In the cases where hæmatoporphyrin has been found in otherwise normal individuals and in those numerous pathological conditions in which it has been found at various times, it appears to be of no prognostic or diagnostic value, nor can I find reports of any fatal cases of this kind where autopsy might throw some light on the subject.

In the cases of lead intoxication it appears to be a much more constant symptom, though here, too, it is without any grave import, but seems to subside gradually with the improvement of the lead symptoms, finally disappearing after the lead symptoms themselves have gone.

In contradistinction to the benign character of this symptom in all other conditions, is its grave and fatal meaning when it is a symptom of sulphonal-poisoning.

In regard to the etiology of this condition we are still very much in the dark. Smith (33) believed that sulphonal formed a definite organic compound-ethyl-sulphonic acid-which acted deleteriously on the blood. But Salkowski (34) and Kast (35) showed that the administration of this substance did not produce any hæmatoporphyrinuria, and the latter believed that the cumulative effect of the sulphonal directly upon the blood was the true cause.

The experiments of Stokvis ( 7 ) led him to believe that hæmorrhages into the mucous membrane of the stomach were produced by the sulphonal, lead, etc., which being transformed by the 
digestive acids into hæmatoporphyrin was reabsorbed and excreted by the kidneys. This conclusion is also supported by those cases where hæmatoporphyrin was found following hæmorrhages into the digestive tract, and by other experiments of Stokvis where he fed rabbits on large quantities of raw meat and found hæmatoporphyrin in their urine.

On the other hand, experiments along the same lines by Kast and Kries (36) failed to produce any changes in the digestive mucous membrane, and reports of autopsies do not mention any evidences of such hæmorrhages.

On another point quite a number of the autopsies agree, namely, that there is a well-marked damage to the renal epithelium, especially of the convoluted tubules and of Henle's loops, similar to the changes found in our own case. The very plausible explanation suggests itself that the renal epithelium is damaged by the passage through it of an irritant, which is formed in some other part of the body through the deleterious action of a poison, be it sulphonal, lead or what not. Where this takes place is as yet undetermined. Evidently not in the digestive tract, as Nencki and Sieber (37) have shown that when hæmatoporphyrin is fed to dogs, it appears in the fæces but never in the urine.

\section{CONCLUSIONS.}

I. Hæmatoporphyrinuria occurs occasionally in a number of different pathological conditions, and even physiologically; more frequently in hæmorrhages into the alimentary canal and in leadpoisoning; and, finally, after the use of sulphonal and applied substances.

2. As a diagnostic and a prognostic sign it is of little value, except in connection with sulphonal-poisoning, where it becomes of very grave prognostic import, especially in women.

3. Its origin is obscure, may not always be the same, and in sulphonal intoxication seems to be associated with a badly damaged renal epithelium, probably of a secondary nature.

4. It is a condition that is more easily prevented than cured. 


\section{LITERATURE.}

I. Mulder and Van Gondovoer.-Journal für praktische Chemie, I844, xxxii.

2. Hoppe-Seyler--Medicinisch-chemische Untersuchung, 1871, 4. Heft.

3. MacMunn.-Proceedings of the Royal Society, 1880 , xxxi.

4. Le Nobel.-Pfluger's Archiv, No. 40.

5. Goya.-Centralblatt für medicinische Wissenschaft, 1892 .

6. Garrod.-The Journal of Pathology and Bacteriology, vol. v, No. 2.

7. Stokvis.-Zeitschrift für klinische Medicin, xxviii, I. Heft.

8. Binnendijk.-Verhandlung v. het Genootschap tel bevording von Natur-Genesse en Heelkunde.

9. Nakarai.-Deutsches Archiv für klinische Medicin, lviii, 2. Heft.

10. Schulte.-Same, lviii, 4 . Heft.

II. Sobernheim.-Deutsche medicinische Wochenschrift, I892, No. 24

12. Garrod.-The Journal of Pathology and Bacteriology, vol. i, No. 2.

13. Friedlander.-Therapeutische Monatshefte, 1894.

14. Salkowski.-Zeitschrift. für physiologische Chemie, I89I, xv.

15. Jolles.-Internationale klinische Rundschau, 1891, Nos. 49-50.

16. Stern.-Deutsche medicinische Wochenschrift, 1894 .

17. Hammersten.-Upsala Forhandlingar, 1890.

18. Mueller.-Wiener klinische Wochenschrift, 1894, vii, No. 14.

19. Panking and Pardington.-The Lancet, ii.

20. Schaffer.-Therapeutische Monatsschrift, 1893.

21. Bresslauer.-Wiener medicinische Blatter, 1891, Nos. I-2.

22. Oswald.-Glasgow Medical Journal, January, I895.

23. Marthen.-Muenchener medicinische Wochenschrift, April, 1895 .

24. Pollitz.-Vierteljahrsschrift für gerichtliche Medicin, Bd. xv, 2. Heft.

25. Wien.-Berliner klinische Wochenschrift, 1898, No. 39.

26. Schultze.-Deutsche medicinische Wochenschrift, 1894, No. 7.

27. Herting.-Same, 1894, No. 15.

28. Beyer.-Same, 1896, No. I.

29. Reinicke.-Same, 1895, No. 10.

30. Goldmann.-Therapeutische Monatshefte, November, 1894.

31. Von Jaksch.- “ Klinische Diagnostic."

32. Bresslauer and Joachim.-Centralblatt für die gesammte Therapie, August, 1895.

33. Smith.-Zeitschrift für physiologische Chemie, xvii.

34. Salkowski.-Virchow's Archiv, lxvi.

35. Kast.-Archiv für experimentelle Pathologie und Pharmakologie, xxxi.

36. Kast and Kries.-Berliner klinische Wochenschrift, I888.

37. Nencki and Sieber.-Archiv für experimentelle Pathologie und Pharmakologie, xxiv. 